\title{
PENERAPAN MEDIASI DALAM PENYELESAIAN PERKARA \\ DI PENGADILAN AGAMA
}

\section{Tomy Saladin}

Fakultas Syariah dan Ekonomi Islam

IAIN Syekh Nurjati Cirebon

Jl. Perjuangan By Pass Sunyaragi Cirebon

Email :saladintomy@gmail.com

\begin{abstract}
Abstrak
Mediator memiliki peran sangat penting akan keberhasilan mediasi. Oleh karena itu, mereka harus memiliki kemampuan yang baik agar proses mediasi dapat berjalan lancar dan sesuai dengan prosedur yang telah diatur dalam Perma Nomor 1 Tahun 2008 Tentang Prosedur Mediasi di Pengadilan. Setiap pemeriksaan perkara perdata di pengadilan harus diupayakan perdamaian dan mediasi sendiri merupakan kepanjangan upaya perdamaian. Mediasi akan menjembatani para pihak dalam menyelesaikan masalah yang buntu agar mencapai/memperoleh solusi terbaik bagi mereka. Selanjutnya ditegaskan bahwa peradilan agama sebagai peradilan keluarga haruslah dimaksudkan tidak sebagai peradilan biasa. Maknanya, hanya melaksanakan kekuasaan kehakiman secara tradisional dan kaku dalam menyelesaikan sengketa keluarga yang diajukan kepadanya.
\end{abstract}

\section{Kata Kunci: Penerapan, Mediasi dan Pengadilan}

\begin{abstract}
Mediators have a very important role to the success of mediation. Therefore, they must have a good ability to make the mediation process work smoothly and in accordance with the procedures set forth in Perma Number 1 Year 2008 About Mediation Procedure in Court. Any trial of civil cases in court should be pursued peace and mediation itself is an extension of the peace effort. Mediation will bridge the parties in solving the deadlock problem in order to achieve / obtain the best solution for them. Furthermore, it is emphasized that the religious court as a family court should be intended not as an ordinary justice. Meaning, it only exercises the traditional and rigid judicial authorities in settling family disputes filed against it.
\end{abstract}

Keywords: Implementation, Mediation and Court 



\section{A. Pendahuluan}

Sebagai metode penyelesaian sengketa secara damai, mediasi mempunyai peluang yang besar untuk berkembang di Indonesia. Dengan adat ketimuran yang masih mengakar, masyarakat lebih mengutamakan tetap terjalinnya hubungan silaturahmi antar keluarga atau hubungan dengan rekan bisnis daripada keuntungan sesaat apabila timbul sengketa.

Menyelesaikan sengketa di pengadilan mungkin menghasilkan keuntungan besar apabila menang, namun hubungan juga menjadi rusak. Menyelamatkan muka (face saving) atau nama baik seseorang adalah hal penting yang kadang lebih utama dalam proses penyelesaian sengketa di Negara berbudaya Timur, termasuk Indonesia.

Mediasi merupakan salah satu instrumen efektif penyelesaian sengketa non-litigasi yang memiliki banyak manfaat dan keuntungan. Manfaat dan keuntungan menggunakan jalur mediasi antara lain adalah bahwa sengketa dapat diselesaikan dengan win-win solution, waktu yang digunakan tidak berkepanjangan, biaya lebih ringan, tetap terpeliharanya hubungan antara dua orang yang bersengketa dan terhindarkannya persoalan mereka dari publikasi yang berlebihan.

Mediasi tidak hanya bermanfaat bagi para pihak yang bersengketa, melainkan juga memberikan beberapa manfaat bagi dunia peradilan. Pertama, mediasi mengurangi kemungkinan menumpuknya jumlah perkara yang diajukan ke pengadilan. Banyaknya penyelesaian perkara melalui mediasi, dengan sendirinya akan mengurangi penumpukan perkara di pengadilan. Kedua, sedikitnya jumlah perkara yang diajukan ke pengadilan akan memudahkan pengawasan apabila terjadi kelambatan atau kesengajaan untuk melambatkan pemeriksaan suatu perkara untuk suatu tujuan tertentu yang tidak terpuji. Ketiga, sedikitnya jumlah perkara yang diajukan ke pengadilan tersebut juga akan membuat pemeriksaan perkara di pengadilan berjalan cepat.

Kewajiban mediasi bagi pihak yang berperkara bermakna sangat luas, para pihak diwajibkan untuk melakukan mediasi dalam menyelesaikan segala perkara perdata sepanjang tidak dikecualikan dalam Pasal 4. Kecuali perkara yang diselesaikan melalui prosedur pengadilan niaga, pengadilan hubungan industrial, keberatan atas putusan Badan Penyelesaian Sengketa Konsumen, dan keberatan atas putusan Komisi Pengawasan Persaingan Usaha, semua sengketa perdata yang diajukan ke Pengadilan Tingkat Pertama wajib lebih dulu diupayakan penyelesaian melalui perdamaian dengan bantuan mediator.

Tindakan hakim dalam mendamaikan para pihak yang bersengketa adalah untuk menghentikan persengketaan dan mengupayakan agar perceraian tidak terjadi. Hakim yang mempunyai andil dalam mengupayakan perdamaian adalah hakim dalam sidang perkara perceraian ketika sidang perkara dimulai, sedangkan mediator merupakan seorang hakim yang ditunjuk oleh hakim majelis untuk mengupayakan perdamaian bagi para pihak di luar sidang pengadilan berdasarkan kesepakatan para pihak. Mediator meiliki peran menentukan dalam suatu proses mediasi. Gagal tidaknya mediasi juga sangat ditentukan oleh peran yang ditampilkan mediator. Mediator berperan aktif dalam menjembatani sejumlah pertemuan antara para pihak.

B. Hukum Islam

1. Pengertian dan Prinsip-prinsip Hukum Islam

Istilah hukum Islam terdiri dari dua buah kata yang berasal dari bahasa Arab yaitu kata Hukum dan kata Islam. 
Kata Hukum berarti ketentuan atau ketetapan, sedangkan kata Islam berasal dari kata "aslama" menjadi "salama" selanjutnya menjadi Islam yang artinya, selamat, damai, sejahtera, atau penyerahan diri sepenuhnya kepada Tuhan. Dari kedua pengertian tersebut maka dapatlah ditarik kesimpulan bahwa yang diartikan dengan hukum Islam secara etimologis ialah segala macam ketentuan atau ketetapan mengenai suatu hal dimana ketentuan itu telah diatur dan ditetapkan oleh agama Islam.

Hukum Islam adalah hukum yang dibangun berdasarkan pemahaman manusia atas nash Al-Qur'an maupun Al-Sunnah untuk mengatur kehidupan manusia yang berlaku secara universal. Keuniversalan hukum ini sebagai kelanjutan langsung dari hakikat Islam sebagai agama universal, yakni agama yang substansi-substansi ajaranNya tidak dibatasi oleh ruang dan waktu manusia, melainkan berlaku bagi semua orang Islam di manapun, kapanpun, dan kebangsaan apa pun. Adapun hukum Islam biasanya disebut dengan beberapa istilah atau nama yang masing-masing menggambarkan sisi atau karakteristik tertentu hukum tersebut. Setidaknya ada empat nama yang sering dikaitkan kepada hukum Islam yaitu syariah, fiqih, hukum syarak, dan qanum.

Di dalam buku Pengantar Hukum Indonesia, juga dijelaskan mengenai pengertian hukum Islam bahwa hukum Islam atau (syariat Islam) ialah kaidahkaidah hukum yang mengatur perbuatan dan sikap manusia terhadap dua arah, yaitu mengatur hubungan manusia dengan Tuhannya (Khaliknya), dan mengatur hubungan manusia dengan manusia lainnya. Bertolak dari pengertian tersebut, jelaslah bahwa hukum Islam merupakan hukum yang sangat lengkap mengatur hubungan manusia dengan menciptanya (Khablumminallah), dan hubungan manusia dengan sesama manusia (Khablumminannaas). Hukum yang mengatur hubungan antara manusia dengan Penciptanya termasuk dalam tataran hukum ibadah, sedangkan hukum yang mengatur hubungan antara manusia dengan sesama manusia masuk dalam tataran hukum muamalaat.

Mengenai prinsip-prinsip hukum Islam, Hasbi as-Shiddiqy menegemukakan beberapa prinsip yang disebutnya dengan Mabadi ${ }^{\text {ie }}$ al-ahkam, yaitu:

a. Prinsip ketauhidan.

b. Prinsip masing-masing hamba berhubungan langsung dengan Allah.

c. Prinsip menghadapi kitab dengan akal.

d. Prinsip memagari akidah dengan akhlak.

e. Prinsip menjadikan beban hukum untuk kewajiban jiwa dan kesuciannya.

f. Prinsip agama dengan dunia dalam masalah hukum.

g. Prinsip persamaan.

h. Prinsip menyerahkan masalah ta ${ }^{e c}$ zir pada pertimbangan penguasa tahkim.

i. Prinsip tahkim (penyelesaian perkara sesuai dengan prosedur hukum)

j. Prinsip amar maeruf nahi mungkar.

k. Prinsip tasamuh.

1. Prinsip kemerdekaan.

Azhar Basyir mengemukakan beberapa prinsip umum Hukum Islam, sebagai berikut:

a. Prinsip akidah yang benar.

b. Prinsip meniadakan perantara antara manusia dengan Tuhan.

c. Prinsip menengah dalam segala hal.

d. Prinsip tolong menolong.

e. Prinsip keadilan dan persatuan.

f. Prinsip musyawarah.

g. Prinsip kebebasan.

h. Prinsip toleransi.

i. Prinsip solidaritas. 


\section{Tujuan Hukum Islam}

Tujuan hukum Islam tidak terbatas pada lapangan materiel saja yang sifatnya sementara, tidak pula kepada hal-hal yang sifatnya formil belaka, akan tetapi lebih dari itu hukum Islam memperhatikan pelbagai faktor seperti faktor Individu, faktor masyarakat dan faktor kemanusiaan dalam hubungannya satu dengan yang lain demi terwujudnya keselamatan di dunia dan kebahagiaan di hari kemudian.

Dalam lapangan ibadat (shalat, puasa, zakat, dan naik haji) dimaksudkan:

a. Membersihkan jiwa manusia dan mempertemukan dirinya dengan Tuhan. Tujuan ini menyangkut kesehatan rohani;

b. Kesehatan jasmani;

c. Kebaikan individu dan masyarakat dan pelbagai seginya.

Dalam lapangan Muamalat, tujuantujuan tersebut di atas juga nampak jelas antara lain pada prinsip yang mengatakan:

a. Menolak bahaya didahulukan daripada mendatangkan kebaikan.

b. Kepentingan umum ditempatkan di atas kepentingan pribadi dan golongan.

Dengan berpegang pada prinsipprinsip tadi, maka beberapa bentuk perikatan atau kontrak dilarang seperti kontrak pinjam-meminjam uang dengan bunga (riba), kawin kontrak, dan lain-lain.

Hukum Islam sesuai substansial selalu menekankan perlunya menjaga kemaslahatan manusia. Hukum Islam senantiasa memperhatikan kepentingan dan perkembangan kebutuhan manusia yang pluralistik. Secara praktis kemaslahatan itu tertuju kepada tujuantujuan, yaitu:

a. Memelihara kemaslahatan agama.

b. Memelihara kemaslahatan jiwa.

c. Memelihara kemaslahatan keturunan. d. Memelihara kemaslahatan harta benda.

Secara substansial, teori maqashid al-syariah adalah untuk mewujudkan kebaikan sekaligus menghindarkan keburukan atau menarik manfaat dan menolak mudharat. Inilah yang biasa disingkat dengan istilah maslahat atau kemaslahatan. Karenanya setiap penetapan dan pengembangan hukum Islam senantiasa bermuara pada basis kemaslahatan itu. Imam al-HaramainalJuwaini dalam buku Amir Mualim, menekankan pentingnya teori Maqashid al-syariah itu sebagai persyaratan utama yang harus dimiliki oleh seorang mujtahid (ahli hukum Islam). karena dengan memahami teori itu berarti mujtahid telah memahami pula tujuan Allah menitahkan perintahperintah demikian pula laranganlaranganNya, sehingga ia mampu mengeluarkan hukum secara benar. Kemudian Imam tersebut mengelaborasi Maqashid al-syariah dengan mengaitkannya dengan illat (motif), asl (tujuan syariat), dan membedakan menjadi tiga kategori, (1) dharuriyyah (primer), (2) al-hajjah alammah (sekunder), (3) makramat (tersier).

3. Ruang Lingkup Hukum Islam

Menurut Ahmad Azhar Basyir, hukum Islam mengatur perikehidupan manusia secara menyeluruh, mencakup segala macam aspeknya. Hubungan manusia dengan Allah diatur dalam bidang ibadat dan hubungan manusia dengan sesamanya diatur dalam bidang muamalat dalam arti luas, baik yang bersifat perorangan maupun bersifat umum, misalnya perkawinan, pewarisan, hukum perjanjian, ketatanegaraan, kepidanaan, peradilan, dan seterusnya. Dalam pandangan Azhar Basyir, jika dihubungkan dengan Ilmu Hukum dikenal adanya klasifikasi hukum privat dan hukum publik, dalam hukum Islam pun dikenal adanya pembagian tersebut dengan 
ditambahkan satu kelompok lagi, yaitu hukum ibadat. Dengan demikian dalam hukum Islam dikenal klasifikasi tersendiri, yaitu hukum privat Islam, hukum publik Islam dan hukum ibadat. Klasifikasi yang disebutkan terakhir menunjukkan bahwa hukum Islam itu mencakup dua dimensi, dunia dan hari kemudian.

Berkaitan dengan pembagian hukum Islam tersebut, Mushthafa Ahmad Az-Zarqae mengemukakan beberapa aspek hukum Islam ke dalam tujuh bidang, yaitu:

a. Hukum-hukum yang berhubungan dengan peribadatan kepada Allah, seperti shalat, puasa, haji, bersuci dari hadas dan sebagainya. Kelompok hukum ini disebut Hukum Ibadat.

b. Hukum-hukum yang berhubungan dengan tata kehidupan keluarga, seperti: perkawinan, perceraian, hubungan keturunan, nafkah keluarga, kewajiban anak terhadap orang tua dan sebagainya. Kelompok hukum ini disebut Hukum Keluarga (al-Ahwal AsySyakhshiyyah).

c. Hukum-hukum yang berhubungan dengan pergaulan hidup dalam masyarakat mengenai kebendaan dan hak-hak serta penyelesaian persengketaan-persengketaan, seperti perjanjian jual beli, sewamenyewa, utang-piutang, gadai, hibah, dan sebagainya. Kelompok hukum ini disebut Hukum Muamalat.

d. Hukum yang berhubungan dengan tata kehidupan bernegara, seperti hubungan penguasa dengan rakyat, pengangkatan kepala negara, hak dan kewajiban penguasa dan rakyat timbal balik dan sebagainya. Kelompok hukum ini disebut AlAhkam as-Sulthaniyah atau asSiyasah as-Syar"iah, yang yang mencakup hal-hal yang dibahas dalam Hukum Tata Negara
Pemerintahan sebagaimana dikenal dewasa ini.

e. Hukum-hukum yang berhubungan dengan kepidanaan, seperti macammacam perbuatan pidana dan ancaman pidana. Kelompok hukum ini disebut al-,,Uqubat, dan sering disebut juga al-JinAyat (Hukum Pidana).

f. Hukum-hukum yang mengatur hubungan antara negara Islam dengan negara-negara lain, yang terdiri dari aturan-aturan hubungan pada waktu damai dan pada waktu perang. Kelompok hukum ini disebut as-Sair (Hukum Antar Negara).

g. Hukum-hukum yang berhubungan dengan budi pekerti, kepatutan, nilai baik dan buruk seperti: mengeratkan hubungan persaudaraan, makan minum dengan tangan kanan, mendamaikan orang yang berselisih dan sebagainya. Kelompok hukum ini disebut al-Adab (Hukum Sopan Santun). Kelompok terakhir dalam praktik tidak menjadi materi pelajaran hukum Islam, tetapi merupakan materi akhlak.

Pengelompokan cakupan hukum Islam tersebut sekaligus berupaya mendetailkan ruang lingkup hukum Islam seperti halnya sistem-sistem hukum lainnya. Lain halnya menurut Amir Syarifuddin, ruang lingkup dalam hukum dalam hukum Islam baik yang terdapat Al-qur'an dan Hadis secara garis besarnya dapat dikelompokkan menjadi tiga bagian, yaitu:

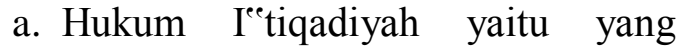
mengatur hubungan rohaniah antara manusia dengan Tuhan dan hal-hal yang menyangkut dengan keimanan. Hukum dalam bidang kemudian berkembang menjadi ilmu-ilmu Ushuluddin.

b. Hukum-hukum khuluqiah yang menyangkut tingkah laku dan moral lahir manusia dalam kehidupan beragama dan bermasyarakat. 
Hukum ini berkembang kemudian menjadi ilmu Akhlak.

c. Hukum-hukum amaliyah yang manyangkut hubungan lahiriah antara manusia dengan Tuhannya, dengan sesama manusia dan dengan alam sekitarnya. Hukum ini berkembang menjadi ilmu Syariah.

\section{Mediasi, Konsep dan Penerapannya}

1. Pengertian, Landasan Hukum, dan Ruang Lingkup Mediasi

Secara etimologi, istilah mediasi berasal dari bahasa Latin, mediare yang berarti berada di tengah. Makna ini merujuk pada peran yang ditampilkan pihak ketiga sebagai mediator dalam menjalankan tugasnya menengahi dan menyelesaikan sengketa antara para pihak. Berada di tengah ${ }^{\text {ee }}$ juga bermakna mediator harus berada pada posisi netral dan tidak memihak dalam menyelesaikan sengketa. Ia harus mampu menjaga kepentingan para pihak yang bersengketa secara adil dan sama, sehingga menumbuhkan kepercayaan dari para pihak yang bersengketa.

Dalam Kamus Lengkap Bahasa Indonesia, kata mediasi diberi arti sebagai proses pengikutsertaan pihak ketiga (sebagai mediator atau penasihat) dalam penyelesaian suatu perselisihan. Pengertian mediasi yang diberikan Kamus Lengkap Bahasa Indonesia mengandung tiga unsur penting. Pertama, mediasi merupakan proses penyelesaian perselisihan atau sengketa yang terjadi antara dua pihak atau lebih. Kedua, pihak yang terlibat dalam penyelesaian sengketa adalah pihak-pihak yang berasal dari luar pihak yang bersengketa. Ketiga, pihak yang terlibat dalam penyelesaian sengketa tersebut tersebut bertindak sebagai penasihat dan tidak memiliki kewenangan apa-apa dalam pengambilan keputusan.

J. Folberg dan A. Taylor lebih menekankan konsep mediasi pada upaya yang dilakukan mediator dalam menjalankan kegiatan mediasi. Kedua ahli ini menyatakan bahwa penyelesaian sengketa melalui jalur mediasi dilakukan secara bersa-sama oleh pihak yang bersengketa dan dibantu oleh pihak yang netral. Mediator dapat mengembangkan dan menawarkan pilihan penyelesaian sengketa, dan para pihak dapat pula mempertimbangkan tawaran mediator sebagai suatu alternatif menuju kesepakatan dalam penyelesaian sengketa.

Garry Goopaster memberikan defenisi mediasi sebagai proses negosiasi pemecahan masalah di mana pihak luar yang tidak memihak (imparsial) bekerja sama dengan pihakpihak yang bersengketa untuk membantu mereka memperoleh kesepakatan perjanjian untuk memuaskan. Goopaster mencoba mengeksplorasi lebih jauh makna mediasi tidak hanya dalam pengertian bahasa, tetapi ia juga menggambarkan proses kegiatan mediasi, kedudukan dan peran pihak ketiga, serta tujuan dilakukan suatu mediasi.

Menurut Takdir Rahmadi, mediasi adalah suatu proses penyelesaian sengketa antara dua pihak atau lebih melalui perundingan atau cara mufakat dengan bantuan pihak netral yang tidak memiliki kewenangan memutus. Pihak netral tersebut disebut mediator dengan tugas memberikan bantuan prosedural dan substansial. Lain halnya dengan pengertian mediasi oleh Jimmy Joses Sembiring bahwa mediasi adalah proses penyelesaian sengketa dengan perantara pihak ketiga, yakni pihak yang memberi masukan-masukan kepada para pihak untuk menyelesaikan sengketa mereka. Di Indonesia, pengertian mediasi secara lebih konkret dapat ditemukan dala Peraturan Mahkamah Agung RI No. 02 Tahun 2003 tentang Prosedur Mediasi di Pengadilan. Mediasi adalah penyelesaian sengketa melalui proses perundingan para pihak dengan dibantu 
oleh mediator (Pasal 1 butir 6). Mediator adalah pihak yang bersifat netral dan tidak memihak, yang berfungsi membantu para pihak dalam mencari berbagai kemungkinan penyelesaian sengketa (Pasal 1 butir 5)

Pengertian mediasi dalam Peraturan Mahkamah Agung RI Tahun 2003 tidak jauh berbeda dengan esensi mediasi yang dikemukakan oleh para ahli resolusi konflik. Namun, pengertian ini menekankan pada satu aspek penting yang mana mediator proaktif mencari berbagai kemungkinan penyelesaian sengketa. Mediator harus mampu menemukan alternatif-alternatif penyelesaian sengketa. Ia tidak hanya terikat dan terfokus pada apa yang dimiliki oleh para pihak dalam penyelesaian sengketa mereka. Mediator harus mampu menawarkan solusi lain, ketika para pihak tidak lagi memiliki alternatif penyelesaian sengketa, atau para pihak sudah mengalami kesulitan atau bahkan terhenti (deadlock) dalam penyelesaian sengketa mereka. Di sinilah peran penting mediator sebagai pihak ketiga yang netral dalam membantu penyelesaian sengketa. Oleh karenanya, mediator harus memiliki sejumlah skill yang dapat memfasilitasi dan membantu para pihak dalam penyelesaian sengketa mereka.

Dalam upaya perdamaian, tahap pertama yang harus dilakukan oleh hakim dalam menyidangkan perdamaian kepada pihak-pihak yang bersengketa adalah mengadakan perdamaian kepada pihak-pihak yang bersengketa. Kewajiban hakim dalam mendamaikan pihak-pihak yang berperkara adalah sejalan dengan tuntunan ajaran Islam. Ajaran Islam memerintahkan agar menyelesaikan setiap perselisihan yang terjadi di antara manusia sebaiknya dengan jalan perdamaian (islah), ketentuan ini adalah sejalan dengan firman Allah SWT dalam Al-Qur'an Surah AlHujurat Ayat (9) yang berbunyi,
"Sesungguhnya orang-orang mukmin adalah bersaudara karena itu damaikanlah antara kedua saudaramu dan bertakwalah kepada Allah supaya kamu mendapat rahmat." yakni bahwa jika dua golongan orang beriman bertengkar maka damaikanlah mereka, perdamaian itu hendaklah dilakukan dengan adil dan benar sebab Allah sangat mencintai orang yang berlaku adil.

Adapun landasan hukum dalam penerapan mediasi di Indonesia diantaranya:

a. HIR Pasal 130 dan Rbg Pasal 154 telah mengatur lembaga perdamaian. Hakim wajib terlebih dahulu mendamaikan para pihak yang berperkara sebelum perkaranya diperiksa.

b. SEMA No. 1 tahun 2002 tentang pemberdayaan lembaga perdamaian dalam Pasal 130 HIR/154 Rbg.

c. PERMA Nomor 2 tahun 2003 tentang prosedur mediasi di Pengadilan.

d. PERMA Nomor 1 tahun 2008 tentang prosedur mediasi di Pengadilan.

e. Mediasi atau APS di luar Pengadilan diatur dalam Pasal 6 UU Nomor 30 tahun 1999 tentang Arbitrase dan Alternatif Penyelesaian Sengketa.

Mediasi sekarang ini telah berkembang ke hal-hal yang lain sepanjang masalah perdata. Oleh karena itu cakupan yurisdiksinya sangat luas. Yurisdiksi tersebut juga sampai kepada masalah perceraian dalam arti mendamaikan para pihak supaya jangan cerai dan masalah sengketa perdata lainnya. Pengadilan Agama mempunyai jurisdiksi untuk melakukan perdamaian dalam arti agar para pihak yang berperkara tidak bercerai. Biasanya para pihak yang datang ke pengadilan agama telah berkonsultasi kepada BP4 (Badan Penasehat Perkawinan dan Penyelesaian Perkara). Namun meskipun para pihak langsung datang 
ke pengadilan agama tanpa melalui BP4, perkara tetap di periksa. Para pihak yang datang ke Pengadilan agama baik yang sudah melalui BP4 maupun yang belum, Hakim agama yang memeriksa dan mengadili perkara tersebut tetap diwajibkan untuk melakukan upaya agar para pihak yang bersengketa mendapat perdamaian. Dalam hal terjadi kesepakatan, maka pihak penggugat mencabut perkaranya. Dalam wilayah hukum privat, titik berat kepentingan terletak pada kepentingan perorangan (pribadi). Dimensi privat cukup luas cakupannya yang meliputi dimensi hukum keluarga, hukum kewarisan, hukum kekayaan, hukum perjanjian (kontrak) bisnis, dan lainnya. Dalam dimensi hukum privat atau perdata, para pihak yang bersengketa dapat melakukan penyelesaian sengketanya melalui jalur hukum di pengadilan maupun di luar jalur pengadilan. Hal ini sangat dimungkinkan karena hukum privat atau perdata, titik berat kepentingannya terletak pada para pihak yang bersengketa, bukan negara atau kepentingan umum. Oleh karena itu, tawar-menawar dan pembayaran sejumlah kompensasi untuk menyelesaikan sengketa dapat terjadi dalam dimensi ini. Dalam hukum Islam, dimensi perdata mengandung hak manusia (Haqqul ibad) yang dapat dipertahankan melalui kesepakatan damai antara para pihak yang bersengketa.

Mediasi sebagai salah satu bentuk penyelesaian sengketa memiliki ruang lingkup utama berupa wilayah privat atau perdata. Sengketa-sengketa perdata berupa sengketa keluarga, waris, kekayaan, kontrak, perbankan, bisnis, dan lingkungan hidup serta berbagai jenis sengketa perdata lainnya dapat diselesaikan melalui jalur mediasi. Penyelesaian sengketa melalui jalur mediasi dapat ditempuh pengadilan maupun di luar pengadilan. Mediasi yang dijalankan di pengadilan merupakan bagian dari rentetan proses hukum di pengadilan, sedangkan bila mediasi dilakukan di luar pengadilan, maka proses mediasi tersebut merupakan bagian tersendiri yang terlepas dari prosedur hukum acara pengadilan.

Dalam perundang-undangan Indonesia ditegaskan ruang lingkup sengketa yang dapat dijalankan kegiatan mediasi. Dalam UU No. 30 Tahun 2000 tentang Arbitrase dan Alternatif Penyelesaian Sengketa disebutkan bahawa sengketa atau beda pendapat perdata dapat diselesaikan oleh para pihak melalui alternatif penyelesaian sengketa yang didasarkan pada itikad baik dengan menyampingkan penyelesaian secara litigasi di Pengadilan Negeri (Pasal 6). Ketentuan dalam Pasal ini memberi ruang gerak cukup luas, yaitu seluruh perbuatan hukum yang termasuk dalam ruang lingkup perdata. Bahkan undangundang ini memberikan penegasan ruang lingkup yang berbeda antara arbitrase dan mediasi.

Hal senada juga ditegaskan dalam Peraturan Mahkamah Agung RI No. 2 Tahun 2003 tentang Prosedur Mediasi di Pengadilan. Dalam Pasal 2 Perma No.2 Tahun 2003 disebutkan bahwa semua perkara perdata yang diajukan ke pengadilan tingkat pertama wajib terlebih dahulu diselesaikan melalui perdamaian dengan bantuan mediator. Ketentuan Pasal ini menggambarkan bahwa ruang lingkup sengketa yang dapat dimediasi adalah seluruh perkara perdata yang menjadi kewenangan peradilan umum dan peradilan agama pada tingkat pertama.

\section{Tujuan dan Manfaat Mediasi}

Mediasi merupakan salah satu bentuk dari alternatif penyelesaian sengketa di luar pengadilan. Tujuan dilakukannya mediasi adalah menyelesaikan sengketa antara para pihak dengan melibatkan pihak ketiga yang netral dan imparsial. Mediasi 
dapat mengantarkan para pihak ketiga pada perwujudan kesepakatan damai yang permanen dan lestari, mengingat penyelesaian sengketa melalui mediasi menempatkan kedua belah pihak pada posisi yang sama, tidak ada pihak yang dimenangkan atau pihak yang dikalahkan (win-win solution). Dalam mediasi para pihak yang bersengketa proaktif dan memiliki kewenangan penuh dalam pengambilan keputusan. Mediator tidak memiliki kewenangan dalam pengambilan keputusan, tetapi ia hanya membantu para pihak dalam menjaga proses mediasi guna mewujudkan kesepakatan damai mereka.

Penyelesaian sengketa melalui jalur mediasi sangat dirasakan manfaatnya, karena para pihak telah mencapai kesepakatan yang mengakhiri persengketaan mereka secara adil dan saling menguntungkan. Bahkan dalam mediasi yang gagal pun, di mana para pihak belum mencapai kesepakatan, sebenarnya juga telah merasakan manfaatnya. Kesediaan para pihak bertemu di dalam proses mediasi, paling tidak telah mampu mengklarifikasikan akar persengketaan dan mempersempit perselisihan di antara mereka. Hal ini menunjukkan adanya keinginan para pihak untuk menyelesaikan sengketa, namun mereka belum menemukan format tepat yang dapat disepakati oleh kedua belah pihak.

Model utama penyelesaian sengketa adalah keinginan dan iktikad baik para pihak dalam mengakhiri persengketaan mereka. Keinginan dan iktikad baik ini, kadang-kadang memerlukan bantuan pihak ketiga dalam perwujudannya. Mediasi merupakan salah satu bentuk penyelesaian sengketa yang melibatkan pihak ketiga. Mediasi dapat memberikan sejumlah keuntungan antara lain:
a. Mediasi
diharapkan
dapat
menyelesaikan sengketa secara

cepat dan relatif murah dibandingkan dengan membawa perselisihan tersebut ke pengadilan atau ke lembaga arbitrase.

b. Mediasi akan memfokuskan perhatian para pihak pada kepentingan merekan secara nyata dan pada kebutuhan emosi atau psikologis mereka, sehingga mediasi bukan hanya tertuju pada hak-hak hukumnya.

c. Mediasi memberikan kesempatan para pihak untuk berpartisipasi secara langsung dan secara informal dalam menyelesaikan perselisihan mereka.

d. Mediasi memberikan para pihak kemampuan untuk melakukan kontrol terhadap proses dan hasilnya.

e. Mediasi dapat mengubah hasil, yang dalam litigasi dan arbitrase sulit diprediksi, dengan suatu kepastian melalui konsensus.

f.Mediasi memberikan hasil yang tahan uji dan akan mampu menciptakan saling pengertian yang lebih baik di antara para pihak yang bersengketa karena mereka sendiri yang memutuskannya.

g. Mediasi mampu menghilangkan konflik atau permusuhan yang hampir selalu mengiringi setiap putusan yang bersifat memaksa yang dijatuhkan oleh hakim di pengadilan atau arbiter pada lembaga arbitrase.

Dalam kaitan dengan keuntungan mediasi, para pihak dapat mempertanyakan pada diri mereka masing-masing, apakah mereka dapat hidup dengan hasil yang dicapai melalui mediasi (meskipun mengecewakan atau lebih buruk daripada yang diharapkan). Bila direnungkan lebih dalam bahwa hasil kesepakatan yang diperoleh melalui jalur mediasi jauh lebih baik, bila dibandingkan dengan para pihak terusmenerus berada dalam persengketaan yang tidak pernah selesai, meskipun 
kesepakatan tersebut tidak seluruhnya mengakomodasikan keinginan para pihak. Pernyataan win-win solution pada mediasi, umumnya datang bukan dari istilah penyelesaian itu sendiri, tetapi dari kenyataan bahwa hasil penyelesaian tersebut memungkinkan kedua belah pihak meletakkan perselisihan di belakang mereka.

Pertemuan secara terpisah dengan para pihak dapat lebih meyakinkan pihak yang lemah akan posisi mereka, sehingga mediator dapat berupaya mengatasinya melalui saran dan pendekatan yang dapat melancarkan proses penyelesaian sengketa. Proses mediasi dan keahlian mediator menjadi sangat penting dalam kaitannya dengan pencegahan dan penyalahgunaan kekuasaan.

3. Prinsip-prinsip dan Model-model Mediasi di Pengadilan

Dalam berbagai literatur ditemukan sejumlah prinsip mediasi. Prinsip dasar (basic principle) adalah landasan filosofis dari diselenggarakannya kegiatan mediasi. Prinsip atau filosofi ini merupakan kerangka kerja yang harus diketahui oleh mediator, sehingga dalam menjalankan mediasi tidak keluar dari arah filosofi yang melatarbelakangi lahirnya institusi mediasi. David Spencer dan Michael Brogan merujuk pada pandangan Ruth Carlton tentang lima prinsip tersebut adalah prinsip kerahasiaan (confidentiality), prinsip sukarela (volunteer), prinsip pemberdayaan (empowerment), prinsip netralitas (neutrality), dan prinsip solusi yang unik (a unique solution).

Prinsip pertama mediasi adalah kerahasiaan atau confidentiality. Kerahasiaan yang dimaksudkan di sini adalah bahwa segala sesuatu yang terjadi dalam pertemuan yang diselenggarakan oleh mediator dan pihak-pihak yang bersengketa tidak boleh disiarkan kepada publik atau pers oleh masing-masing pihak. Demikian juga sang mediator harus menjaga kerahasiaan dari ini mediasi tersebut, serta sebaiknya ia lakukan. Mediator juga tidak dapat dipanggil sebagai saksi di pengadilan dalam kasus yang ia prakarsai penyelesaiannya melalui mediasi. Masing-masing pihak yang bertikai diharapkan saling menghormati kerahasiaan tiap-tiap isu dan kepentingan masing-masing pihak. Jaminan ini harus diberikan masingmasing pihak, sehingga mereka dapat mengungkapkan masalahnya secara langsung dan terbuka. Hal ini penting untuk menemukan kebutuhan dan kepentingan mereka secara nyata.

Prinsip kedua, volunteer (sukarela). Masing-masing pihak yang bertikai datang ke mediasi atas keinginan dan kemauan mereka sendiri secara sukarela dan tidak ada paksaan dan tekanan dari pihak-pihak lain atau pihak luar. Prinsip kesukarelaan ini dibangun atas dasar bahwa orang akan mau bekerja sama untuk menemukan jalan keluar dari persengketaan mereka, bila mereka datang ke tempat perundingan atas pilihan mereka sendiri.

Prinsip ketiga, pemberdayaan atau empowerment. Prinsip ini didasarkan pada asumsi bahwa orang yang mau datang ke mediasi sebenarnya mempunyai kemampuan untuk menegosiasikan masalah mereka sendiri dan dapat mencapai kesepakatan yang mereka inginkan. Kemampuan mereka dalam hal ini harus diaku dan dihargai, dan oleh karena itu setiap solusi atau jalan penyelesaian sebaiknya tidak dipaksakan dari luar. Penyelesaian sengketa harus muncul dari pemberdayaan terhadap masing-masing pihak, karena hal itu akan lebih memungkinkan para pihak untuk menerima solusinya.

Prinsip keempat, netralitas (neutrality). Di dalam mediasi, peran seorang mediator hanya memfasilitasi prosesnya saja, dan isinya tetap 
menjadi milik para pihak yang bersengketa. Mediator hanyalah berwenang mengontrol proses berjalan atau tidaknya mediasi. Dalam mediasi, seorang mediator tidak bertindak layaknya seorang hakim atau juri yang memutuskan salah atau benarnya salah satu pihak atau mendukung pendapat dari salah satunya, atau memaksakan pendapat dan penyelesaiannya kepada kedua belah pihak.

Prinsip kelima, solusi yang unik (a unique solution). Bahwasanya solusi yang dihasilkan dari proses mediasi tidak harus sesuai dengan standar legal, tetap dapat dihasilkan dari proses kreativitas. Oleh karena itu, hasil mediasi mungkin akan lebih banyak mengikuti keingingan kedua belah pihak, yang terkait erat dengan konsep pemberdayaan masing-masing pihak. Dalam pelaksanaan mediasi di berbagai negara di dunia, proses pendamaian perkara di pengadilan yang dilakukan oleh hakim terbagi menjadi beberapa bentuk yang dipengaruhi oleh siapa yang menjadi mediator, gaya mediasi dilakukan, apakah hakim boleh berperan menjadi mediator dalam kasus yang sama, serta jenis kesepakatan yang dihasilkan. Empat bentuk atau model tersebut adalah:

a. Judicial settlement.

Model ini lebih banyak dipakai di negara bersistem hukum Eropa Kontinental dimana hakim diamanatkan oleh hukum tertulis untuk mencoba mendamaikan sengketa sebelum memeriksa perkara. Namun belakangan, hakim di negara AngloSaxon mulai memakai model ini berdasarkan diskresi mereka tanpa diwajibkan oleh peraturan yang mengatur. Dalam sistem hukum AngloSaxon, model ini banyak dilakukan dalam pemeriksaan perkara oleh juri (jury trial), ketika hakim merahukan kemampuan pengacara para pihak melakukan negosiasi untuk kepentingan klien mereka, atau ketika hakim meyakini kemampuan sendiri untuk menyelesaikan.

Judicial settlement hanya dilakukan di pengadilan dan dilakukan oleh hakim yang sama yang akan memeriksa perkara. Jadi hakim tersebut berperan ganda sebagai pendamai dan pemutus perkara. Dalam prakteknya, bentuk ini mempunyai gaya direktif, legalistik, dan diselenggarakan dalam waktu singkat, walaupun akhir-akhir ini sudah banyak mengalami variasi. Namun peran ganda hakim dalam model ini menimbulkan kekhawatiran tentang perlakuan yang adil kepada para pihak.

b. Judicial mediation.

Model ini dilakukan oleh hakim yang bukan pemeriksa perkara setelah para pihak yang bersengketa sepakat untuk mencoba mediasi. Apabila tidak berhasil mencapai kesepakatan, maka mediator yudisial tersebut dilarang untuk ikut serta dalam proses pemeriksaan perkara. Semua dokumen yang ada pada mediator yudisial tersebut dimusnahkan setelah proses mediasi selesai. Pemisahan yang tegas antara tugas hakim sebagai pendamai dan pemutus perkara diberlakukan.

Judicial mediation telah dilaksanakan dengan sukses di Quebec, Kanada. Di Amerika Serikat, model ini lebih mengutamakan peran pensiunan hakim sebagai mediator karena dianggap memiliki waktu yang lebih banyak hingga bisa fokus memediasi. Di Jerman, model ini fokus pada penyelesaian sengketa dengan batas waktu yang ketat dan gaya yang direktif.

c. Judicial moderation.

Di negara bagian Bavaria-Jerman, model ini mulai dicoba dengan mengembangkan peran fasilitatif hakim untuk mendamaikan perkara. Selain itu, model ini juga dipakai di CalgaryKanada dan Australia. Berbeda dengan Bavaria, dua negara terakhir ini membolehkan hakim yang sama untuk menjadi mediator menganalisa sebuah kasus cocok untuk dimediasi, maka dia 
kemudian menghubungi para pihak dan menawarkan perannya sebagai moderator. Bila berhasil mencapai kesepakatan, maka judicial mediator menyusun drfat kesepakatan. Bila gagal, kasus tersebut dikembalikan kepada majelis hakim pemeriksa perkara dan tidak ada upaya lagi untuk menyelesaikan perkara secara damai. Judicial moderation dikenal juga dengan nama conferencing atau judicial dispute resolution. Teknik yang digunakan lebih luas dibandingkan dengan yang ditawarkan oleh juducial settlement atau judicial mediation, meliputi investigasi perkara, memberikan arah dan nasehat, menata sengketa, dan intervensi fasilitatif. Model ini tidak terbatas pada satu proses. Moderator melakukan intervensi berdasarkan diskresi mereka disesuaikan dengan kebutuhan para pihak.

d. Facilitative judging.

Dalam model ini, hakim tidak hanya dilatih keahlian pengambilan keputusan dan proses adjudikasi tradisional, tetapi mereka juga dibekali kemampuan komunikasi dan fasilitasi. Semua keahlian ini diberikan untuk membantu hakim dalam menyelesaikan kasus. Model ini disebut juga mediative adjudication, circle sentencing atau problem-solving courts. Tidak ada pemisahan antara tugas hakim yang sama bisa memediasi dan memeriksa perkara. Facilitative judging mempunyai sejarah yang panjang di negara China dan negara Asia lainnya. Model ini juga semakin banyak dipakai di Australia dan Amerika Serikat.

Berdasarkan empat kategori di atas, terminologi yang digunakan sesuai dengan kondisi Indonesia adalah judicial mediation, dimana proses mediasi secara tegas memisahkan peran ganda hakim yaitu sebagai pendamai, dan pemutus perkara.

\section{Tahapan dan Proses Mediasi}

Mengenai tahapan proses mediasi, belum terdapat keseragaman dan pedoman yang baku di antara para sarjana dan praktisi mediasi. Pada umumnya, para sarjana atau praktisi mediasi, mengemukakan tahapan proses mediasi berdasarkan pengalaman mereka menjadi mediator. Berikut ini akan dikemukakan beberapa pendapat mengenai proses mediasi.

Ada beberapa tahapan mediasi secara umum, yaitu:

a. Tahap Pendahuluan (Preliminary)

a) Dibutuhkan suatu proses "pemahaman"e yang cukup sebelum suatu proses mediasi dimulai misalnya; apa yang menjadi sengketa?

b) konsultasi dengan para pihak tentang tempat dan waktu mediasi, identitas pihak yang hadir, aturan tempat duduk, dan sebagainya.

b. Sambutan Mediator

a) Menerangkan urutan kejadian.

b) Meyakinkan para pihak yang masih ragu.

c) Menerangkan peran mediator dan para pihak.

d) Menegaskan bahwa para pihak yang bersengketalah yang berwenang untuk mengambil keputusan.

e) Menyusun aturan dasar dalam menjalankan tahapan.

f) Memberi kesempatan mediator untuk membangun kepercayaan dan menunjukkan kendali atas proses.

g) Mengonfirmasi komitmen para pihak terhadap proses.

c. Presentasi Para Pihak

a) Setiap pihak diberi kesempatan untuk menjelaskan permasalahannya kepada mediator secara bergantian.

b) Tujuan dari presentasi ini adalah untuk memberikan kesempatan kepada para pihak untuk mendengan sejak dini, dan juga memberi kesempatan setiap pihak 
mendengarkan permasalahan dari pihak lainnya secara langsung.

c) Who first? Who desides?

d. Identifikasi Hal-hal yang Sudah Disepakati

Salah satu peran penting bagi mediator adalah mengidentifikasi hal-hal yan telah disepakati antara para pihak sebagai landasan untuk melanjutkan proses negosisasi.

e. Mendefinisikan dan Mengurutkan Permasalahan

Mediator perlu membuat suatu "struktur" dalam pertemuan mediasi yang meliputi masalah-masalah yang sedang diperselisihkan dan sedangberkembang. Dikonsultasikan dengan para pihak, sehingga tersusun daftar permasalahan menjadi suatu agenda.

f. Negosiasi dan pembuatan Keputusan

a) Tahap negosiasi yang biasanya merupakan waktu alokasi terbesar.

b) Dalam model klasik (Directing the traffic), mediator berperan untuk menjaga urutan, struktur mencatat kesepahaman, reframe dan meringkas, dan sekali-kali mengintervensikan membantu proses komunikasi.

c) Pada model yang lain (Driving the bus), mediator mengatur arah pembicaraan, terlibat dengan mengajukan pertanyaan kepada para pihak dan wakilnya.

g. Pertemuan Terpisah

a) Untuk menggali permasalahan yang belum terungkap dan dianggap penting guna tercapainya kesepakatan.

b) Untuk memberikan suasana dinamis pada proses negosiasi bila ditemui jalan buntu.

c) Menjalankan tes realitas terhadap para pihak.

d) Untuk menghindarkan kecenderungan mempertahankan pendapat para pihak pada join sessions.

e) Untuk mengingatkan kembali atas hal-hal yang telah dicapai dalam proses ini dan mempertimbangkan akibat bila tidak tercapai kesepakatan.

h. Pembuatan Keputusan Akhir

a) Para pihak dikumpulkan kembali guna mengadakan negosiasi akhir, dan menyelesaikan beberapa hal dengan lebih rinci.

b) Mediator berperan untuk memastikan bahwa seluruh permasalahan telah dibahas, di mana para pihak.

i.Mencatat Keputusan

a) Pada kebanyakan mediasi, perjanjian akan dituangkan ke dalam tulisan, dan ini bahkan menjadi suatu persyaratan dalam kontrak mediasi.

b) Pada kebanyakan kasus, cukup pokok-pokok kesepakatan yang ditulis dan ditandatangani, untuk kemudian disempurnakan oleh pihak pengacara hingga menjadi suatu kesepakatan akhir.

c) Pada kasus lainnya yang tidak terlalu kompleks, perjanjian final dapat langsung.

j. Kata Penutup

a) Mediator biasanya memberikan ucapan penutup sebelum mengakhiri mediasi.

b) Ini dilakukan untuk memberikan penjelasan kepada pihak atas apa yang telah mereka capai, meyakinkan mereka bahwa hasil tersebut merupakan keputusan mereka sendiri, serta mengingatkan tentang hal apa yang perlu dilakukan di masa mendatang.

c) Mengakhiri mediasi secara formal.

Adapun prosedur dan tahapan mediasi di pengadilan diatur dalam Pasal 3 sampai Pasal 14 Peraturan Mahkamah Agung RI Nomor 2 Tahun 2003 tentang Prosedur Mediasi di Pengadilan. Mediasi di pengadilan dibagi dalam dua tahap yaitu tahap pra mediasi dan tahapan pelaksanaan 
mediasi. Tahap pramediasi adalah tahap di mana para pihak mendapatkan tawaran dari hakim untuk menggunakan jalur mediasi dan para pihak menunjuk mediator sebagai pihak ketiga yang akan membantu menyelesaikan sengketa mereka.

Dalam pra mediasi, hakim memberikan waktu satu hari kerja kepada pihak setelah sidang pertama untuk memilih dan menunjuk mediator di luar pengadilan. Dalam tahap pelaksanaan mediasi, Peraturan Mahkamah Agung Nomor 2 tahun 2003 memberikan batas waktu yang berbeda antara mediasi yang menggunakan mediator yang disediakan pengadilan dengan mediasi yang menggunakan mediator di luar pengadilan. Bagi para pihak yang menggunakan mediator di pengadilan diberikan waktu penyelenggaran mediasi paling lama 22 hari kerja sejak pemilihan atau penetapan penunjukan mediator. Bagi para pihak yang menggunakan mediator diluar daftar mediator yang dimiliki oleh pengadilan, berlangsung paling lama 30 hari kerja untuk menyelenggarakan mediasi. Dalam waktu paling lama tujuh hari kerja setelah pemilihan atau penunjukan mediator, para pihak wajib menyerahkan fotokopi dokumen yang memuat duduk perkara, fotokopi suratsurat yang diperlukan, dan hal-hal yang terkait dengan sengketa kepada mediator (Pasal 8).

Dokumen ini sangat penting bagi mediator untuk mempelajari duduk perkara, sehingga ia dapat menentukan faktor penyebab terjadinya sengketa antar para pihak. Mediator harus mempelajari secara sungguh-sungguh seluruh dimensi yang berkaitan dengan perkara yang menjadi pokok sengketa para pihak. Para pihak harus menyerahkan seluruh dokumen dan surat-surat penting yang berkaitan dengan perkaranya kepada mediator. Di samping itu, sesama para pihak juga diharapkan saling memberikan dokumen atau surat-surat yang berkaitan dengan pokok sengketa, sehingga para pihak sama-sama saling mempelari berkas satu sama lain.

Jika mediator merasakan cukup atas informasi yang diperoleh dari jumlah dari sejumlah dokumen dan surat dari para pihak, maka tugas mediator adalah menentukan jadwal pertemuan denga para pihak yang bersengketa, guna menyelesaikan proses mediasi. Pada saat itulah mediator memberikan penjelasan mengenai posisi dirinya dalam rangka membantu para pihak menemukan solusi terhadap sengketa mereka, mengemukakan aturan mediasi yang dapa disepakati bersama dan menekankan bahwa otoritas pengambilan keputusan tetap berada di tangan para pihak. Dalam proses mediasi tersebut para pihak dapat didampingi oleh kuasa hukumnya. Keberadaan kuasa hukum dalam suatu proses mediasi harus mendapatkan persetujuan para pihak lain, karena kalau tidak akan mempersulit langkah mediasi dan bahkan dapat terancam gagalnya mediasi. Jelasnya keberadaan orang lain selain para pihak dan mediator dalam proses mediasi mendapat persetujuan bersama para pihak.

Dalam menjalankan proses mediasi, mediator diberikan kebebasan untuk menciptakan sejumlah peluang yang memungkinkan para pihak menemukan kesepakatan yang dapat mengakhiri sengketa mereka. Mediator harus sungguh-sungguh mendorong para pihak untuk memikirkan sejumlah kemungkinan yang dapat dibicarakan guna mengakhiri persengketaan. Jika dalam proses mediasi terjadi perundingan yang menegangkan, mediator dapat menghentikan mediasi untuk beberapa saat guna meredam suasana agak lebih kondusif. Bahkan Pasal 9 Ayat (1) Perma memberikan kesempatan bagi mediator untuk melakukan kaukus. Kaukus adalah 
pertemuan antara mediator dengan salah satu pihak tanpa dihadiri oleh pihak lainnya.

Keputusan melakukan kaukus berada di tangan mediator, dan sebaiknya juga harus mendapat tujuan dengan para pihak. Mediator harus mempertimbangkan sisi positif dan sisi negatif bila kaukus diselenggarakan, karena penyelenggaran kaukus kadangkadang juga menimbulkan kecurigaan salah satu pihak kepada mediator atau kepada pihak lain. Namun, pada sisi lain kaukus diperlukan, karena dapat mengantisipasi situasi di mana para pihak tidak dapat saling dipertemukan secara berhadapan.

\section{Kesimpulan}

Penerapan mediasi di pengadilan dalam proses penyelesaian sengketa perkawinan sejalan dengan hukum Islam, di mana perceraian adalah suatu perbuatan yang dimurkai oleh Allah SWT, sebagaimana dalam hadist yang diriwAyatkan oleh Ibnu Umar ra., "Rasulullah SAW bersabda, perbuatan yang halal yang paling dibenci Allah adalah thalaq (cerai)."

Bahkan Pasal 7 Ayat (1) Perma telah mewajibkan hakim untuk menyelesaikan sengketa tersebut melalui mekanisme mediasi. Selain itu, Pasal 2 Ayat (4) mengharuskan hakim memasukkan hasil mediasi ke dalam pertimbangan hukumnya dan jika tidak menempuh prosedur mediasi dianggap sebagai pelanggaran terhadap Pasal 130 HIR/154 RBg yang berakibat putusan batal demi hukum sebagaimana Pasal 2 Ayat (3) Perma. Dengan demikian, mediasi sebagai alternatif penyelesaian sengketa di luar persidangan menjadi suatu keharusan dalam penyelesaian sengketa perdata.

Diwajibkan mediasi khususnya dalam sengketa perkawinan seperti perceraian membawa manfaat yang besar bagi para pihak, karena melalui mediasi akan dicapai kesepakatan dan solusi yang memuaskan dan terselesaikannya problem yang menjadi penyebab keretakan rumah tangga sehingga keutuhan rumah tangga tetap terjaga.

\section{DAFTAR PUSTAKA}

Abdul Manan, Penerapan Hukum Acara Perdata di Lingkungan Peradilan Agama, Jakarta: Kencana Prenada Media, 2005

Abdullah Marlang, Irwansyah, dan Kaisaruddin Kamaruddin, Pengantar Hukum Indonesia, Makassar: A.S. Center, 2009

Ahmad Azhar Basyir, Asas-asas Hukum Muamalat (Hukum Perdata Islam), Yogyakarta: UII Press, 2000

Amir Mualim dan Yusdani, Ijtihad dan Legislasi Muslim Kontemporer, Yogyakarta: UII Press, 2005

Amir Syarifuddin, Pembaharuan Pemikiran dalam Hukum Islam, Padang: Angkasa Raya, 1990

Fatahillah A. Syukur, Mediasi Yudisial Di Indonesia Bandung: Mandar Maju, 2012

Gary Goopaster, Negosiasi dan Mediasi: Sebuah Pedoman

Negosiaisi dan Penyelesaian Sengketa Melalui Negosiasi, Jakarta: ELIPS Project, 1993

Jimmy Joses Sembiring, Cara Menyelesaikan Sengketa di Luar Pengadilan, Jakarta: Visimedia, 2011

John Michael Hoynes, Cretchen L. Haynes dan Larry Sun Fang, Mediation: Positive Conflict Management, New York: SUNY Press, 2004

M. Arfin Hamid, Hukum Islam Perspektif Keindonesiaan (Sebuah Pengantar dalam Memahami Relaitas di Indonesia), Makassar: PT. Umitoha Ukhuwah Grafika, 2011

Mahkamah Agung RI, Peraturan Mahkamah Agung Republik Indonesia Nomor 1 Tahun 2008 tentang Prosedur Mediasi di Pengadilan 
Mustofa dan Abdul Wahid, Hukum Islam Kontemporer, Jakarta: Sinar Grafika, 2009

Nurnaningsih Amriani, Mediasi Alternatif Pennyelesaian Sengketa Perdata di Pengadilan, Jakarta: PT Rajagrafindo Persada, 2011

Said Agil Husin Al-Munawar, Hukum Islam \& Pluralitas Sosial, Jakarta: Penamadani, 2004

Sudikno Mertokusumo, Hukum Acara Perdata Indonesia, Yogyakarta: Liberty Yogyakarta, 2009

Susanti Adi Nugroho, Mediasi Sebagai Alternatif Penyelesaian Sengketa, Jakarta: Telaga Ilmu Indonesia, 2009

Syahrizal Abbas, Mediasi dalam Hukum Syariah, Hukum adat, dan Hukum Nasional, Jakarta: Kencana Prenada Media Group, 2011

Syahrizal Abbas, Mediasi dalam Hukum Syariah, Hukum Adat, dan Hukum Nasional, Jakarta: Kencana Prenada Media Group, 2011

Takdir Rahmadi, Mediasi Penyelesaian Sengketa Melalui Pendekatan Mufakat, Jakarta: PT Rajagrafindo Persada, 2010 